\title{
Arabic Creative and Participative Learning: In Search of a New Way of Language Learning by “EI Jidal Reborn” Youth Community in Malang
}

\author{
${ }^{1}$ Wildana Wargadinata, ${ }^{2}$ Iffat Maimunah, ${ }^{3}$ Saidna Zulfiqar Bin Tahir, ${ }^{4} \mathrm{M}$ Chairul Basrun \\ Umanailo \\ 1,2 Universitas Islam Negeri Maulana Malik Ibrahim Malang, Indonesia \\ 3,4 Universitas Iqra Buru, Maluku, Indonesia \\ I'wildana@bsa.uin-malang.ac.id, ${ }^{2}$ iffatmaimunah@uin-malang.ac.id, \\ ${ }^{3}$ saidnazulfiqar@gmail.com, ${ }^{4}$ chairulbasrun@gmail.com
}

\begin{abstract}
The development of language skills and competencies of students experiencing various obstacles originates from the precise nature of learning. The need for developing language skills among students is inevitable, as is the need for Arabic, in the millennial era, in line with the integration of students into global communication and knowledge networks. Arabic has also become a source of knowledge in addition to other languages. The Language community in the millennial era cannot be seen as a meaningless community because its existence is an alternative way out in developing language skills that prioritize active, cooperative, and collaborative learning activities using participatory approaches. This paper shows that the development of community-based language skills has had implications for the success of language learning, as a counterpart to formal and standard language learning practices. As shown in this paper, the existence of a language community is a transformation of the learning process that is informal by providing facilities for students to carry out the process of learning, training, and mentoring that promotes active learning models, cooperative-collaborative, participatory in a language community. This paper suggests the need for a model for developing language skills through communities by formulating learning models based on collaborative achievement development, in response to individualistic language learning traditions.
\end{abstract}

Keywords: participative learning, skill development, language community, informal learning, el-jidal reborn

\section{Introduction:}

The development of language skills is a necessity for students who are studying in the language department, but various factors have hampered students' competence in the language. The need for Arabic is inevitable in the millennial era in line with the integration of students into the global communication and knowledge network. Sources of knowledge come from various languages, including Arabic. Ghani et al. showed that $53.1 \%$ of students had moderate Arabic language skills, 35.8\% of them had low ability, while only $11.1 \%$ of them had the competence (Ghani et al., 2011). This fact confirms that language development has become a necessity for students. Difficulties in Arabic can include significant aspects of the Arabic language, such as listening, speaking, reading, and interrelated writing (Sam, 2016). All four elements of learning Arabic have been approached with a variety of methods, including learning communities that combine active and collaborative learning activities that accommodate academic activities with social events that go beyond the classroom. Such complementary approaches are believed to have an impact on behavior to promote openness to diversity, social tolerance, and personal and interpersonal development (Zhao \& Kuh, 2004).

So far, the study of learning Arabic tends to talk about "language skills development," which is based on three perspectives. First, studies that examine the issue of developing language skills that focus on the teacher only. Arabic language skills development refers only to active teachers and passive students 
(Hidayat, 2012; M. Khalilullah, 2011; Sarip Hidayat, 2012). Secondly, studies that pay attention to the development of language skills in the material and the development of language skills in the classroom are very passive, where the teacher's very central position in the class closes the space for active Arabic practice. Third, studies that pay attention to the issue of language development takes place through formal institutions. The strategy of developing Arabic only through formal education in educational institutions has been assessed as an approach with an ineffective model or strategy (Abdul Manaf, 2017; Alanazi \& Widin, 2018). From these three trends, it appears that Arabic education has been structured top-down both through formal educational institutions and through learning models that involve teachers. The bottom-up Arabic learning process that is based on student creativity does not get attention.

The purpose of this paper is to complement the shortcomings of existing studies, which tend to place language development skills as formal structured and conducted by official institutions. This research, in contrast to existing ones, emphasizes education in an informal, participatory, and collaborative manner. Therefore, the present study aims to answer three questions: (a) how does the process of developing Arabic language skills in the "El Jidal Reborn" language community take place?; (b) what factors determine the success of the "El Jidal Reborn" language community in developing Arabic language skills?, and (c) how to design the development of Arabic language skills in the "El Jidal Reborn" community more effectively?.

This paper is based on the argument that language skills can not only be developed in formal institutions but can also take place through the Language community. Through the language community, a language development system is created through participatory activities that involve peer tutors among members of the language community. Fellow community members form cultures that reinforce and motivate each other in achieving shared commitment in developing language skills. In other words, the cooperative learning approach to developing language skills may ease the difficulties in learning Arabic that tend to be formal.

\section{Literature Review}

\subsection{Language Skill}

Language is a symbol that is used and interpreted as a means of communication to others (Fridani et al., 2014). Quoting from Megawati (2016), each language has different characteristics and uniqueness so that an understanding is needed to facilitate human communication. Correspondingly, Fridani et al. (2014) explained that each language has a character that it identifies into several aspects such as systematic, arbitrator (mediator), flexible, many meanings, and sophisticated. Therefore, Segal \& Collin-Vézina (2019) said that a good ability is needed to overcome the uniqueness and abundance of languages. Where this is marked by the development of skills, skills, intelligence, and skills in using and applying language to facilitate communication. In contrast, Suherman (2008) states that competencies or abilities in language can develop if each individual understands, comprehends, and utilizes what he/she has learned. Therefore, the understanding of proper language use will improve the ability of all aspects of life for each individual. Language skills have become a strategy in implementing the ease of learning systems in schools. According to Wong \& Nunan (2011), relevant learning strategies today are language acquisition, which provides awareness and awareness that leads to more effective.

Development and improving language skills is a central ability for every individual to engage in social relationships and access practical learning experiences (Dockrell \& Marshall, 2015). Dickinson \& Porche (2011) asserted that language skills are fundamental in influencing the abilities and knowledge of every child, starting from reading, writing, speaking, and listening. Therefore, language skills influence children to have high intellectual and thought patterns in components such as critical thinking, evaluation, and research (Gil-Glazer et al., 2019). It is because language supports them having new knowledge through 
vocabulary and skills in grammatical structures. Therefore, language helps them understand the description and describe the situation (Gil-Glazer et al., 2019). This fact is supported by Brown et al. (2011) that necessary language skills can support children's sensitivity in understanding phenomena and understanding knowledge. Language skills encourage children to analyze vocabulary so that they will get a higher interpretation in processing and responding to information so that it supports the formation of historical understanding (Brown et al., 2011).

\subsection{Learning Community}

Learning community is one of the essential aspects that must be present in classroom learning, especially in the application of language lessons. The learning community is very influential in seeing student involvement in achieving learning goals in the classroom. The learning community was created to assist everyone in meeting their learning needs (solving and facing learning difficulties) and achieving learning goals (Liu et al., 2010). In this case, the learning community is defined as an interactive media that plays a role in supporting learning both inside and outside the classroom, where this group builds interactions and relationships that form a collective awareness (Liu et al., 2010). Every person who joins the learning community will get knowledge, experience, discussion, practice, and encouragement to like every concept in learning, such as language. This fact is explained by Scott et al. (2017) that the learning community encourages students to understand weaknesses in learning through the assistance of other actors. Where to simplify the practice requires peers as an actor who can know the desires of community members. Therefore, peers are one of the most critical aspects of the learning community. In contrast, Allen (2013) mentions that professional assistants such as teachers are more able to expand conceptual understanding in the learning process. Thus, the teacher can further deepen and harmonize discussions, practices, and objectives of the existence of learning groups (Allen, 2013)

In a learning community, there are several processes undertaken to describe a learning material in the form of (1) defining learning problems; (2) planning a learning model; (3) teaching lessons through peers; (4) evaluating experiences and reflecting their effects; (5) revising the material; (6) sharing the results of the discussion (Stigler\&Hiebert, 1999 Shingphachanh, 2018). The process in this learning community encourages students to use their cooperative intelligence, learning ability, creativity, transfer of knowledge, development towards professional/sustainable expertise (Dawood et al., 2015: 94). Accordingly, Yadav et al. (2016) mentioned that there are four structures related to the integration of the formation of learning communities, such as input into knowledge, information distribution, information interpretation, and learning memory. Therefore, the learning community has an impact on the formation of critical thinking on each individual who reflects and applies the results of learning (van Keulen, 2010). In some literature, case studies that discuss the learning community are always referred to as new students who transfer schools/transfer students (Vaughan, 2010; Young \& Bruce, 2011; Zhang, Xiang, Hospedales, \& Lu, 2018). Where they need the learning community to adapt to learning and existing languages.

\subsection{Skill Development}

The development of skills and abilities has become one of the ways to improve one's quality of self. Gooptu (2018) depicted that training is necessary to improve quality proficiency in various fields. However, it does not only involve technical competence, but the capacity building also requires a process of changing attitudes, dispositions, new identities with various impacts in cultural, social, and political aspects. It aims to develop human resources, so they have skills for the future and the formation of analytical and critical attitudes and mindsets (Gooptu, 2018). Accordingly, competence in improving social skills is often related to capacity. Gooptu \& Chakravarty (2018) identified various dimensions associated with the concept of function that focuses on individuals, communities, and connections or participation. To work on broader social action concepts, clarity of the desired objectives, ways to achieve 
these goals, and better analysis of local dynamics to determine the impact of their implementation (Klingberg, 2014; Ongardwanich, Kanjanawasee, \& Tuipae, 2015; Taylor, Oberle, Durlak, \& Weissberg, 2017). Merino (2012), in research on project development in remote areas, said that factors such as capacity and capacity building are essential for sustainable project development.

In understanding the formation of developing skills, there is an initiation process carried out by each individual. According to Luyten \& Bruggencate (2011), this process includes (1) the introduction phase; (2) the phase of finding meaning and new things; (3) convenience phase; (4) the initiation phase of knowledge; (5) reflection and application phases. In contrast, Jamison et al. (2012) identify the required steps in developing skills in attitudes, thoughts, and language. These steps include: 1) developing ideas in practicing abilities; 2) using tools to improve skills; 3) looking for other learning resources or models that can be applied quickly and fun for children such as combining games and learning; 4) practice; 5) participate in group/community discussions. By so doing, the development of skills will be able to influence behavior change in every child. Bichay-Awadalla et al. (2019) emphasized that there is a very close relationship between behavior and skills. In the study, improving language skills can affect the internalization of values and emotions for every child, where the development of multi-language skills encourages the creation of a sense of interest or behaves aggressively to engage in activities. Also, the development of knowledge about language seems to influence patterns of interaction and learning opportunities in the classroom (Bichay-Awadalla et al., 2019).

\subsection{Language Learning}

Language learning dramatically influences one's skills and knowledge in understanding language. Language learning is a story, not just a vocabulary where the language is used as a necessary process in interpreting and regulating understanding and experience (Gooptu \& Chakravarty, 2018). Quoting from Mubaligh (2010), language is an arbitrary code system that has a close relationship with ideology because every use of language is ideological. Therefore, language is essential in influencing human thought patterns. The fact was made clear by Mubaligh (2010: 112) that language as a tool to influence, change and dominate others so that readers or audiences who will receive and justify messages, ideas, thoughts conveyed believe and even follow. Everyone needs language when interacting, expressing views and opinions, and other social relationships. Concerning the importance of language in social relations, it is essential to pay attention to language learning (Acquisition, 2012; Alqahtani, 2015; Melitz, 2016; Moghadam, Zainal, \& Ghaderpour, 2012). Language learning is the process of understanding or abstracting meaning, interpretation, and understanding of reality in a different way (Fatimah \& Sari, 2018). Therefore, language learning can support the creation of a critical understanding and sensitivity to each individual.

The basic principles of language learning may encompass some aspects, including: first, language as a tool for communication (Beard, 2018; Caplan, 2019); second, language learning involves mastering skills and knowledge (Wengan \& Yaya, 2013); third, students need to consider the emotional impact on language learning ( Shao, Pekrun, \& Nicholson, 2019); and fourth, learners have variations in their approaches to learning. Success in language learning is related to age, talent, motivation, previous language learning experiences, learning styles, beliefs, culture, gender, and self-direction (Hardison et al., 2012). The case study (Wengan \& Yaya, 2013) conducted in China shows that culture influences language learning beliefs and has a significant influence on many of the failures and efficiency of language learning in language learning. Teachers need to be able to encourage students to adopt positive cultural elements in the process of learning foreign languages so that they can create confidence in the learning of foreign languages, which in the end, the language is not only oriented to knowledge but rather to skills. 


\section{Methods}

The El Jidal Reborn Language Community is a Semi-Autonomous Institute in the Student Association of the Arabic Language and Literature Department of the Faculty of Humanities. The community that was formed in 2010 is oriented towards developing the interests, talents, and linguistic creativity in the framework of togetherness. Structurally, El Jidal Reborn operates under the student body. This community represents a lively language learning community appearing in various places, as well as a response to difficulties in learning languages, especially Arabic.

The data used in this paper were obtained through observation, interviews, questionnaires, and documentation. Observations were made on community activities in the form of observations on the process of developing language skills. Interviews were conducted with six informants, selected based on seniority and active involvement in the El Jidal Reborn community. The questions include issues of developing language skills practiced within the El Jidal Reborn community. The data obtained through a questionnaire is done by distributing questionnaires containing questions related to aspects of the development of language skills achieved by community members and the conditions of student learning to develop language skills. The questionnaire was distributed to 44 respondents who were chosen based on the overall active members of the community. The documentation used here is a document in the form of policy products related to support for El Jidal Reborn.

Data analysis involves three processes, namely, (1) restatement of data collected in accordance by following their themes, (2) description carried out to find patterns and data trends, and (3) interpretations aimed at understanding the meaning contained in a statement. The data that has been reduced thematically is displayed in the form of pictures, interview excerpts, and related photos. In the final stage, data verification is carried out to give birth to a deep and comprehensive understanding of the data.

\section{Results}

\subsection{The process of developing language skills in the "El Jidal Reborn" community}

"El Jidal Reborn" community is a community among students who have positive efforts in developing language skills. These efforts arose in response to the potential for language skills possessed by students. To develop language skills, the El Jidal Reborn community holds meetings and exercises regularly and is scheduled once a week. The training is carried out more actively and more intensively when going to take part in competitions both at national and international levels. In addition to regular exercise, mastering vocabulary and Arabic terms is an effort to develop language skills in the El Jidal community, in addition to each member committing to mutually reinforcing their competencies.

The development of language skills in the "El Jidal Reborn" language community includes four aspects of language skills, namely, listening, speaking, reading, and writing. The four scopes of language skills are implemented by the El Jidal Reborn community in several fields, namely: (1) Listening and speaking including the areas of debate, news reading, and speech, (2) Reading covers the fields of classical books reading, and poetry reading and (3) essay writing.

The development of the three skills is carried out under the guidance of a tutor. The tutor is a senior member of the El Jidal Reborn community and some lecturers of the Arabic Language and Literature. The development of debate skills begins with the delivery of theory by the tutor, an exercise in the delivery of insights, arguments and questions, and answers by each debate member. While the method of developing 
news reading skills is carried out with news reportage exercises, taking the examples from Arabic videos. For the speech is done by mastering the art of rhetoric and practice stringing words. For classic books, reading carried out by mastering Arabic rules, the practice of reading the book and understanding the meaning contained in the book. The poetry reading is carried out with poetry understanding, studying the poet's profile, then repeated reading of poetry, and understanding the contents of poetry. And the essay writing is done by mastering Arabic terms and vocabulary, the practice of writing texts repeatedly using a beautiful and proper sentence structure. Reference in developing debate skills uses a standardized reference in the Qatar Debate System. While the media used in the development of the news breaking reading and speech skills are Arab videos accessed from Arab television broadcasts such as Al-Jazirah. The source of learning for the development of classical books reading skills is the classic Arabic book, whereas poetry reading uses learning resources from the work of Arabic poets. As the source of the book of Arabic essay 'also comes from the essay work of prominent Arab writers.

The development process has brought amazing results that appear from a series of achievements they have achieved. The progress in the past one year include the General Champion Student Level in the Arab Fest event at Padjadjaran University on 29 September 2019, as the overall champion of this championship won the West Java Governor Cup Ridwan Kamil, with details of the tournament as follows; The first winner for the news reading contest by Faizatul Widad, the first winner speech competition by $\mathrm{M}$. Shofiuddin Alfaris, the first winner of poetry reading by M. Choirul Umam and second winner for the Arabic debate contest by Aad Nur Sayyidus Syuhuur B., Mar'atun Nailur Rif'ah and Arina Haque. In the PIONIR 2019 Arabic debate event on July 23, 2019, won the second place by Aad Nur Sayyidus Syuhuur B. In the al-Buthulah event al-Yunisiyah li al-Munadharat bi al-Lughah al-Arabiyah UII Jogjakarta on 15 April 2019 won third place in the international debate competition. In addition to winning the championship in the language competition event, the El-jidal Reborn language community also succeeded in delivering Muhammad Sahni Arja as the only participant from Indonesia who passed the Elite Debate Academy Arabic selection held by the Qatar Debate Association.

\subsection{Factors that Determine the Success of the "EI Jidal Reborn" Language Community}

The success in developing language skills that can be achieved by the El Jidal Reborn Language community is based on several factors. One influential factor is the motivation that arises from members. The members of the El Jidal Reborn community are very enthusiastic and enthusiastic about developing language skills with an adequate environment. This confession was expressed by Khozinul Asror, one of the El Jidal Reborn community members;

"Before participating in the mosque, I had involved in a debate competition, and at that time, I felt lost because I had never studied before. Finally, after joining El Jidal Reborn, a spirit appeared, I tried to develop my language skills independently with an adequate environment "(Interview 16 October 2019, Khozinul Asror, BSA 2018).

By joining the El Jidal Reborn community, learning laziness decreased and gained a more energetic spirit and motivation, as Marisa Salsabila said;

"Having a study group is very important. So, this El Jidal Reborn study group is an attempt to erode our laziness while learning ”(Interview 17 October 2019, Marisa Salsabila, BSA 2016).

Joining this El Jidal Reborn community makes students helped in the process of developing language skills because there are meetings with people who are competent in the field of language and language skills development. As said by Fika Burhan; 
"After joining EI Jidal Reborn, I feel blessed meeting great people and experts in their respective fields, especially in the field of debate, supported by much learning, much motivation and then there is an opportunity to take part in competitions everywhere"(Interview 16 October 2019, Fika Burhan, BSA 2018).

Marisa Salsabila also said that the presence of the EI Jidal Reborn language community among students was able to be a place to motivate each other in learning among fellow community members.

"In El Jidal Reborn, it is not just learning. Nevertheless, much motivation is given by friends. The thing that motivates is not your teacher but your friend, so really I can know from friends what I did not know before. Moreover, the effect is on our academics. We have an extraordinary impact on us "(Interview 17 October 2019, Marisa Salsabila BSA 2016).

The development of language skills carried out by the EI Jidal Reborn Language community is also based on outside intervention. By joining the El Jidal Reborn community, students get tutors, both peers, tutors, and lecturers, who can assist in developing the language skills of each of their members, as illustrated in the following Diagram 1.

Diagram 1. Student Learning Conditions

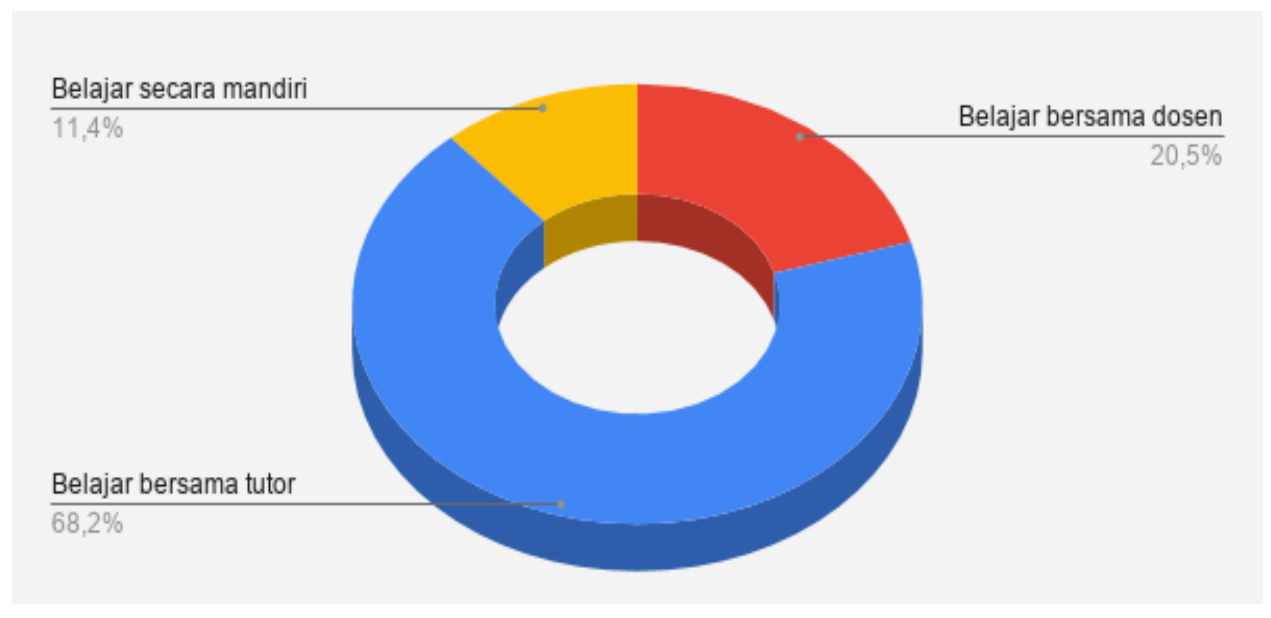

\section{Source: Research Results, 2019}

In Table 1, it appears that the efforts of students in developing language skills independently by $11.4 \%$ and language skills development carried out with the intervention of outsiders amounted to $88.7 \%$.

Support from various parties is an essential factor for the successful development of language skills. This learning community has the support of multiple parties for its existence and role. This community has given birth to a generation that has contributed to the development of Arabic. One of the supports came from the Head of the BSA Department, Halimi Zuhdi, who proudly appreciated the role of the El Jidal Reborn community. He also gave the message, "Give birth to cadre cadets who contribute to Arabic" (https://www.instagram.com/eljidalbsa_reborn/). A senior lecturer guides the El Jidal Reborn community. Likewise, the dean supports the full support of this community. For faculty leaders, the success achieved by the El Jidal Reborn community must be maintained. The achievements of the El Jidal Reborn community in developing language skills are considered as manifestations of the manifestation of the syiar (mission) which is always touted by the El Jidal Reborn community, which reads: 
11 "استقاماتتا واتحادنا لنيل النجاح.... ها أنا ذا..

\section{"Istiqomatuna wa ittihaaduna li nayli an-najaah... Haa Anadza"}

\subsection{A Model for Developing Arabic Skills in an Effective "El Jidal Reborn" Community}

The El Jidal Reborn Language Community does not merely equip students with language skills, and this community aims to provide experience in the field of Arabic language and literary arts accompanied by efforts to develop interests, talents, and creativity. Realizing this effort, El Jidal Reborn developed a useful model. El Jidal Reborn's participation in the race event requires its members to share experiences from competitions that are periodically followed. This sharing of experiences is carried out based on the cooperative-collaborative model between members and facilitators by promoting a participatory approach. The cooperative learning model shows the significant development of language skills. It can be seen in the following Diagram 2.

Diagram 2. Development of Students' Language Ability

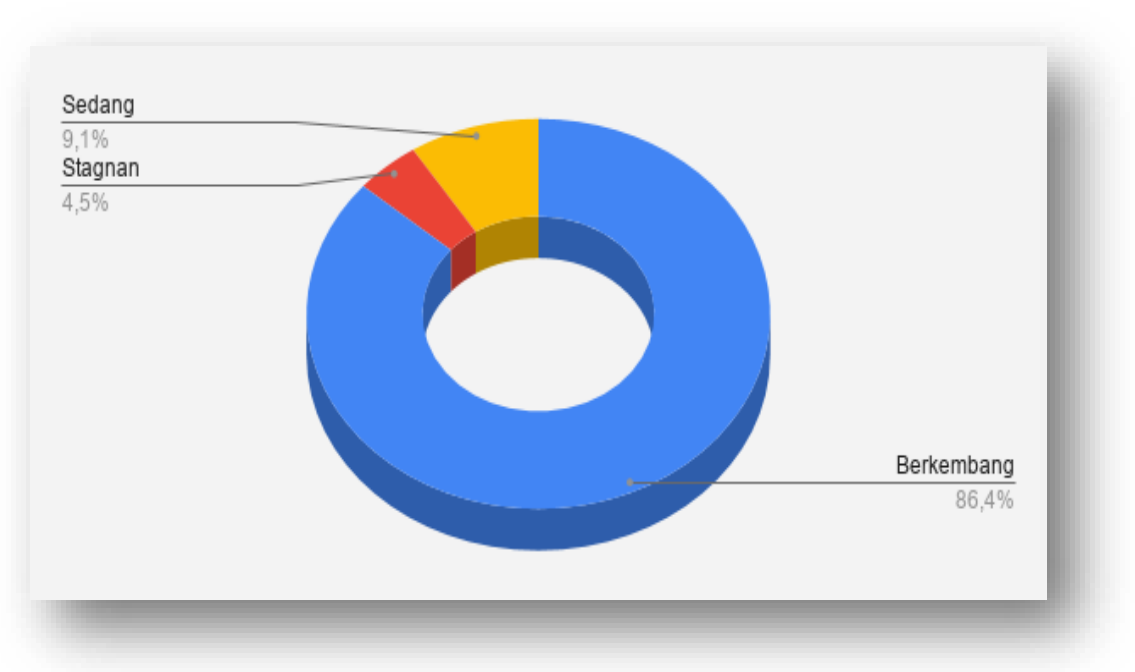

\section{Source: Research Results, 2019}

In addition to the cooperative model, El Jidal Reborn developed a training model and language practicum. As with the development of debate skills, training is an effort to prepare students to be able to compete. As said by Marisa Salsabila;

"In El Jidal Reborn, the emphasis is on exercise. Exercise makes an opinion formed from a problem. Then it was represented in a speaking exercise through debate." (Interview, Marisa Salsabila BSA 2016, on October 17, 2019).

In continuous practice, El Jidal Reborn is a place for sharing, especially sharing about language development. Given language as a product of human civilization, the language will continue to experience growth. Marisa Salsabila recognizes this condition:

"Language is always developing, with El Jidal Reborn we can share, increase knowledge and knowledge." (Interview, Marisa Salsabila BSA 2016, on 17 October 2019). 
As a forum for developing language skills, El Jidal Reborn formulated practical strategies aimed at being a reference for skill development. One member of the El Jidal Reborn community, Fika Burhan, emphasized:

"A good language development model, which can be formulated, in my opinion, is with practice and also sharpens the argument. (Interview, Fika Burhan BSA 2018, on October 17, 2019).

With the development strategy that is carried out together in this El Jidal Reborn community, the development of language skills can be realized gradually. The condition, as mentioned earlier, is in line with what was stated by Rusyda Fauziyah Azadi, that:

"In the past, I learned Arabic only just that. Not able to apply well. Then I looked for a forum through El Jidal Reborn to develop my language. Because it could be, it would be useless if it is not practiced and certainly will not improve. However, after joining El Jidal Reborn, it can develop gradually. "(Interview, Rusyda Fauziyah Azadi BSA 2018, on 17 October 2019).

The statement above shows that the development of language skills that run in El Jidal Reborn is based on a cooperative-collaborative model with a participatory approach, which emphasizes the importance of practice and practicum in a language learning process.

\section{Discussion}

\subsection{From Formal to Informal in Language Learning}

The existence of the language learning community, especially in developing language skills, is a sign of the transformation of the learning system. The learning that was initially institutional-based has changed to be community-based to solve the problem of language difficulties. The practice of developing language skills has shifted the formal learning process to become informal in response to the tendency so far it is still based on the formality of activities. Informalization in learning Arabic, for example, in addition to showing the emergence of new strategies in terms of approach, also indicates a change in the value base of personal relationships that are more open. Students who learn languages make new choices based on psychological comfort in learning. Norman and Schmidt stressed that mental conditions determine a person's success in language learning (Norman \& Schmidt, 1992). In addition to psychological considerations, community-based language learning is also based on the character of individuals who need friendship-based learning.

The shift from an organized institution through a rigid and standard administrative system towards a community-based learning practice has a positive effect on the development of language skills. In community-based learning, students can explore all their potentials to lead to better and more developed conditions in the learning process. From the process of exploring this potential, it enables students to move themselves and their communities to learn more actively without rigid and standard ties. More motivation arises from within students to always find new formulations in learning. It confirms that motivation is the most critical factor in building the learning spirit of each learner (Zimmerman, Bandura, \& Martinez-Pons, 1992).

The shift in orientation in community-based language learning as a whole can be read as a transformation in the tradition of language learning. With a culture of learning created in the community, El Jidal Reborn can demonstrate the development of competencies for all its members. It will undoubtedly have an impact on changing attitudes and mentality of each individual in the community in a more positive direction. Therefore, changes in attitude and positive mindset become elements that must be built by every student to realize the orientation of the learning process undertaken (Petty, Wegener, \& Fabrigar, 
1997) to obtain maximum results. The communal-based learning model in the form of formal and standard shifts in Arabic learning, as practiced by El Jidal Reborn, shows a transformation in learning methods and approaches that are made on conscious choices about contextualization of language learning following student character.

\subsection{Skill Development: Training and Coaching}

The language learning community is a necessary facility for practicing language practice. Language practice requires special skills that must be developed continuously. Continuity in practicing that is carried out in a guided manner will improve language skills effectively. This effectiveness enhances language skills, in addition to an evaluation of learning outcomes must also be held to find out and diagnose the performance of the exercise that has been done. Mennim stressed that language training and practice allows learners to focus on improving language skills through performance that is implemented collaboratively with friends (Mennim, 2012). In improving language skills, performance needs to be diagnosed and evaluated to find out how far students can achieve learning outcomes.

An evaluation of performance and language training can be carried out comprehensively if it is carried out by a competent mentor and can provide an opportunity for students to ask about the difficulties encountered and submit appropriate solutions according to training-based learning procedures. Evaluation of the learning process is not only focused on short-term results or outputs but should reach the outcomes of the learning process that is carried out (Tayibnapis, 2000). The training process must be guided to realize this outcome. Guided language training shapes critical analytical attitudes and mindsets. Critical thinking directs students to understand the concepts of language practice that support the quality of language learning outcomes. Likewise, as said by Veliz \& Veliz-Campos that critical thinking skills are needed to promote success in academic life (Veliz \& Veliz-Campos, 2019), a successful academic life will produce good quality education and learning quality.

Arabic learning that is done by focusing on training and mentoring shows a comprehensive process that continues. The training-based learning process and mentoring, in addition to making it easier to find potential in students (community members), also become an increasingly open sharing space to build togetherness. The relationship between students and mentors/mentors wrapped in exercises provides ample scope for student self-development in the form of better motivation and self-confidence. The improvement of language skills in the El Jidal Reborn community becomes a learning model that is not only limited to the efforts to fulfill maximum language skills, but also a strategy in building togetherness in the learning community.

\subsection{Contextual Teaching and Learning: Development of Student Team Achievement}

The development of learning models is a response to changes and events that occur after the learning process takes place. Developing a language-learning model from a language community should represent a contextual learning model that is relevant to the conditions and situations of students. The contextualization of the learning model can help students understand the concept of learning according to the case being experienced, in addition to teaching how to create relationships between the knowledge students have and apply it in life. Teaching and learning developed, not only rests on the transfer of knowledge, but the removal of values is also developed to students on an ongoing basis. Transfer of expertise aims to equip students with linguistic knowledge and the transfer of benefits as a manifestation that, in addition to being able to speak well, students must also have good morals.

Student life has its style and character. As an 'agent of change,' students implement change and renewal on every side of life. Changes that lead to success are very dependent on the quality and workability of individual learners (Lunenburg, 2010). In this case, students must be able to make changes in the broader 
context of life, including achieving more brilliant success. As agents of change, students "must" play two roles at the same time, namely as objects and subjects of learning. Likewise, with language skills development, success through the community is possible to be achieved by learning models based on student team achievement development. Development of achievements that not only oriented to individuals but also touches the interests of the community as a whole.

A development orientation that favors community (team) achievements requires the involvement of all elements, such as EI Jidal Reborn stakeholders. Various development models carried out so far have focused on how accomplishments have been achieved without leaving other aspects, including efforts to build teams/communities. Changes in the direction of language skills development among students find relevance when the companion and students are placed in an equal position so that they can establish egalitarian cooperation. Thus, the development model that is based on the fulfillment of students' knowledge and character (value) ultimately gives birth to what is called the student team achievement development achieved from the empowering-participatory teaching and learning process.

\section{Conclusion}

The development of language skills has been taking place through both formal and informal institutions. Formally, skill development can be done by designing learning models that are curriculum-based and structured. Informally, language skills development is carried out by involving communities basis on togetherness and family. A language community, like El Jidal Reborn, affirms the achievement of more open learning. The learning process takes place in addition to being supported by egalitarian collaborative nature by paying attention to sociological aspects to meet the needs of students, which includes knowledge and character building. These two things become the path to the achievements of the Language community, especially El Jidal Reborn, so far.

The accomplishment of the Language community does not stand alone because it is supported by the active encouragement of its members to be more advanced. The strong motivation that comes from within a student forms an open learner character. In contrast, the motivation that comes from outside the student reinforces the importance of other parties' involvement in supporting the development of neater and more structured skills. The skills development, therefore, not only rests on the cognitive aspects of students but also psychomotor that forms learner character, which is always based on a commitment to succeed together and is empowering-participatory.

This paper shows the results that developing community-based language skills is a transformation of the learning process from formal to informal. Informalization that runs in the language community shows the process of developing language skills able to answer the needs of students who lead to the achievement of significant success. Although this study only pays attention to how the Language community builds a communal learning culture, it does not deny the importance of the social relations that surround it. The successful development of language skills through this community still needs further study to find more comprehensive skills development formulations to realize the achievements and success of language learning.

\section{References}

1. Abdul Manaf, L. (2017). Cooperative Learning Strategies and their Impact on the Promotion of Editorial Expression Students of the Department of Arabic Language Teaching at the Islamic

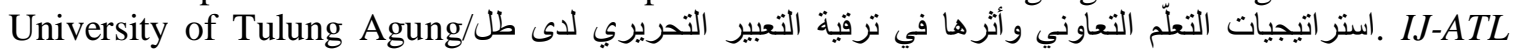
(International Journal of Arabic Teaching and Learning). https://doi.org/10.33650/ijatl.v1i2.293

2. Acquisition, E. L. (2012). Learning words in a second language. Teaching Vocabulary to English Language Learners. 
3. Alanazi, M. J. M., \& Widin, J. (2018). Exploring the Role of Teacher Talk in Saudi EFL Classroom: Importance of F-Move in Developing Students Spoken Skill. SSRN Electronic Journal. https://doi.org/10.2139/ssrn.3151117

4. Allen, D. (2013). Reconstructing professional learning community as collective creation. Improving Schools, 16(3), 191-208. https://doi.org/10.1177/1365480213501056

5. ALQAHTANI, M. (2015). The importance of vocabulary in language learning and how to be taught. International Journal of Teaching and Education. https://doi.org/10.20472/te.2015.3.3.002

6. Beard, A. (2018). Speech, language, and communication: a public health issue across the lifecourse. Pediatrics and Child Health (United Kingdom). https://doi.org/10.1016/j.paed.2017.12.004

7. Bichay-Awadalla, K., Qi, C. H., Bulotsky-Shearer, R. J., \& Carta, J. J. (2019). Bidirectional Relationship Between Language Skills and Behavior Problems in Preschool Children From LowIncome Families. Journal of Emotional and Behavioral Disorders. https://doi.org/10.1177/1063426619853535

8. Brown, D. D., Lile, J., \& Burns, B. M. (2011). Basic language skills and young children's understanding of causal connections during storytelling. Reading Psychology, 32(4), 372-394. https://doi.org/10.1080/02702711.2010.495573

9. Caplan, R. (2019). Epilepsy, language, and social skills. Brain and Language. https://doi.org/10.1016/j.bandl.2017.08.007

10. Dickinson, D. K., \& Porche, M. V. (2011). Relation Between Language Experiences in Preschool Classrooms and Children's Kindergarten and Fourth-Grade Language and Reading Abilities. Child Development, 82(3), 870-886. https://doi.org/10.1111/j.1467-8624.2011.01576.x

11. Dockrell, J., \& Marshall, C. (2015). Measurement issues: Assessing language skills in young children. Child and Adolescent Mental Health, 20(2), 116-125.

12. Fatimah, \& Sari, R. D. K. (2018). Strategi Belajar \& Pembelajaran dalam Meningkatkan Keterampilan Bahasa. Pena Literasi, 1(2), 108-113.

13. Fridani, Lara; Dhieni, N. (2014). Hakikat Perkembangan Bahasa Anak. Metode Pengembangan Bahasa, 1-28.

14. Ghani, K. A., Nik Yusof, N. M. R., Baharuddin, H., Yamat, H., Ahmad, Z., \& Abdullah, I. (2011). Development of a learning module on Arabic Language Skills Outside of the Classroom. Procedia - Social and Behavioral Sciences. https://doi.org/10.1016/j.sbspro.2011.05.023

15. Gil-Glazer, Y., Walter, O., \& Eilam, B. (2019). PhotoLingo-Development and Improvement of Higher-Order Thinking and Language Skills Through Photographs. Journal of Education, 199(1), 45-56. https://doi.org/10.1177/0022057419843523

16. Gooptu, N. (2018). JSAD Special Issue on Skill Development in India. Journal of South Asian Development, 13(3), 241-248. https://doi.org/10.1177/0973174118822391

17. Gooptu, N., \& Chakravarty, R. (2018). Skill, Work and Gendered Identity in Contemporary India: The Business of Delivering Home-Cooked Food for Domestic Consumption. Journal of South Asian Development, 13(3), 293-314. https://doi.org/10.1177/0973174118804448

18. Hardison, C. M., Miller, L. W., Li, J. J., Schroeder, A. N., Burkhauser, S., Robson, S., \& Lai, D. (2012). Background on Adult Language Learning. In Second-Language Skills for All?

19. Hidayat, N. S. (2012). Problematika Pembelajaran Bahasa Arab Oleh: Nandang Sarip Hidayat. Jurnal Pemikiran Islam.

20. Jamison, K. R., Forston, L. D., \& Stanton-Chapman, T. L. (2012). Encouraging Social Skill Development through Play in Early Childhood Special Education Classrooms. Young Exceptional Children, 15(2), 3-19. https://doi.org/10.1177/1096250611435422

21. Klingberg, T. (2014). Childhood cognitive development as a skill. Trends in Cognitive Sciences. https://doi.org/10.1016/j.tics.2014.06.007

22. Liu, I. F., Chen, M. C., Sun, Y. S., Wible, D., \& Kuo, C. H. (2010). Extending the TAM model to 
explore the factors that affect Intention to Use an Online Learning Community. Computers and Education, 54(2), 600-610. https://doi.org/10.1016/j.compedu.2009.09.009

23. Lunenburg, F. C. (2010). Managing change: The role of the change agent. International Journal of Management, Business and Administration.

24. Luyten, H., \& Bruggencate, G. (2011). The presence of matthew effects in dutch primary education, development of language skills over a six-year period. Journal of Learning Disabilities, 44(5), 444-458. https://doi.org/10.1177/0022219411410289

25. M. Khalilullah, S. A. M. (2011). Strategi Pembelajaran Bahasa Arab Aktif (Kemahiran Istima' Dan Takallum). Jurnal Sosial BudayaKhalilullah.

26. Megawati, F. (2016). Kesulitan Mahasiswa Dalam Mencapai Pembelajaran Bahasa Inggris Secara Efektif. Pedagogia, 5(2), 147-156.

27. Melitz, J. (2016). English as a global language. In The Palgrave Handbook of Economics and Language. https://doi.org/10.1007/978-1-137-32505-1

28. Mennim, P. (2012). Learner negotiation of L2 form in transcription exercises. ELT Journal. https://doi.org/10.1093/elt/ccr018

29. Moghadam, S. H., Zainal, Z., \& Ghaderpour, M. (2012). A Review on the Important Role of Vocabulary Knowledge in Reading Comprehension Performance. Procedia - Social and Behavioral Sciences. https://doi.org/10.1016/j.sbspro.2012.11.300

30. Norman, G. R., \& Schmidt, H. G. (1992). The psychological basis of problem-based learning: A review of the evidence. Academic Medicine. https://doi.org/10.1097/00001888-199209000-00002

31. Ongardwanich, N., Kanjanawasee, S., \& Tuipae, C. (2015). Development of 21st Century Skill Scales as Perceived by Students. Procedia - Social and Behavioral Sciences. https://doi.org/10.1016/j.sbspro.2015.04.716

32. Petty, R. E., Wegener, D. T., \& Fabrigar, L. R. (1997). Attitudes And Attitude Change. Annual Review of Psychology. https://doi.org/10.1146/annurev.psych.48.1.609

33. Sam, Z. (2016). Metode Pembelajaran Bahasa Arab. Nukhbatul 'Ulum. https://doi.org/10.36701/nukhbah.v2i1.16

34. Sarip Hidayat, N. (2012). Problematika Pembelajaran Bahasa Arab. Pemikiran Islam.

35. Scott, T. P., Thigpin, S. S., \& Bentz, A. O. (2017). Transfer Learning Community: Overcoming Transfer Shock and Increasing Retention of Mathematics and Science Majors. Journal of College Student Retention: Research, Theory and Practice, 19(3), 300-316. https://doi.org/10.1177/1521025115621919

36. Segal, A., \& Collin-Vézina, D. (2019). Impact of Adverse Childhood Experiences on Language Skills and Promising School Interventions. Canadian Journal of School Psychology, 34(4), 317322. https://doi.org/10.1177/0829573519856818

37. Shao, K., Pekrun, R., \& Nicholson, L. J. (2019). Emotions in classroom language learning: What can we learn from achievement emotion research? System. https://doi.org/10.1016/j.system.2019.102121

38. Shingphachanh, S. (2018). Teachers' understanding and concerns about the practices of lesson study in suburb schools in Laos. International Journal for Lesson and Learning Studies, 7(2), 150-162. https://doi.org/10.1108/IJLLS-12-2017-0062

39. Taylor, R. D., Oberle, E., Durlak, J. A., \& Weissberg, R. P. (2017). Promoting Positive Youth Development Through School-Based Social and Emotional Learning Interventions: A MetaAnalysis of Follow-Up Effects. Child Development. https://doi.org/10.1111/cdev.12864

40. van Keulen, A. (2010). The Early Childhood Educator in a Critical Learning Community: Towards sustainable change. Contemporary Issues in Early Childhood, 11(1), 106-112. https://doi.org/10.2304/ciec.2010.11.1.106

41. Vaughan, N. D. (2010). A blended community of inquiry approach: Linking student engagement and course redesign. Internet and Higher Education. https://doi.org/10.1016/j.iheduc.2009.10.007

42. Veliz, L., \& Veliz-Campos, M. (2019). An interrogation of the role of critical thinking in English 
language pedagogy in Chile. Teaching in Higher Education. https://doi.org/10.1080/13562517.2018.1456424

43. Wengan, J., \& Yaya, Z. (2013). The effects of culture on foreign language learning beliefs. Proceedings of the 2013 IEEE International Conference in MOOC, Innovation and Technology in Education, MITE 2013. https://doi.org/10.1109/MITE.2013.6756372

44. Widoyoko Tayibnapis, F. Y. (2000). Evaluasi Program Pembelajaran. Jurnal Ilmu Pendidikan.

45. Wong, L. L. C., \& Nunan, D. (2011). The learning styles and strategies of effective language learners. System, 39(2), 144-163. https://doi.org/10.1016/j.system.2011.05.004

46. Young, S., \& Bruce, M. A. (2011). Classroom Community and Student Engagement in Online Courses. Learning.

47. Zhang, Y., Xiang, T., Hospedales, T. M., \& Lu, H. (2018). Deep Mutual Learning. Proceedings of the IEEE Computer Society Conference on Computer Vision and Pattern Recognition. https://doi.org/10.1109/CVPR.2018.00454

48. Zhao, C. M., \& Kuh, G. D. (2004). Adding value: Learning communities and student engagement. Research in Higher Education. https://doi.org/10.1023/B:RIHE.0000015692.88534.de

49. Zimmerman, B. J., Bandura, A., \& Martinez-Pons, M. (1992). Self-Motivation for Academic Attainment: The Role of Self-Efficacy Beliefs and Personal Goal Setting. American Educational Research Journal. https://doi.org/10.3102/00028312029003663 